\title{
Business innovation and critical success factors in the era of digital transformation and turbulent times
}

\section{Anna Florek-Paszkowska1 (iD, Anna Ujwary-GiP Bianka Godlewska-Dziobon' ${ }^{3}$}

\begin{abstract}
PURPOSE: Explore what entrepreneurship and success factors can help drive business to resilience and stability and achieve competitive advantage through innovation in different countries and business realities in the era of digital transformation and turbulent times. METHODOLOGY: Based on the narrative literature review, we present research findings concerning new strategies and outlooks for business innovation in times of many unknowns. Each organization wants to find its way to gain success and create its unique business model, which can capture value creation and innovativeness and be more adaptive, resilient, and stable in critical moments and sustainable over time. FINDINGS: The articles presented in this issue explore the essential factors of business innovation and success in different organizations and the environments in which these businesses function. IMPLICATIONS FOR THEORY AND PRACTICE: This article synthesizes the presented research field's importance and relevance, connecting its theoretical background with practical research. Recommendations and implications for future trends of this research stream might also be helpful for professionals and academicians. ORIGINALITY AND VALUE: The novel studies presented in this issue were done in five different (developing and developed) countries and business sectors that present human-based and non-human-based factors as crucial factors needed to empower business transformation in a complex world. Each group of elements is essential in business success, and their components are interdependent. We need to look at the interactions and interdependencies of
\end{abstract}

\footnotetext{
1 Anna Florek-Paszkowska, Ph.D., CENTRUM Católica Graduate Business School and Pontificia Universidad Católica del Perú, Urbanización Los Álamos de Monterrico, Jirón Daniel Alomía Robles 125, Santiago de Surco 15023, Lima, Peru, e-mail: aflorekpaszkowska@pucp.edu.pe (ORCID: https://orcid.org/0000-0002-1249-5069).

2 Anna Ujwary-Gil, Ph.D., Hab. Professor of Institute of Economics, Polish Academy of Sciences, Laboratory of Process and Network Analysis, Nowy Swiat 72, 00-330 Warsaw, Poland, e-mail: ujwary@inepan.waw.pl (ORCID: https://orcid. org/0000-0002-5114-7366).

3 Bianka Godlewska-Dzioboń, Ph.D., Assistant Professor, Cracow University of Economics, Rakowicka 27, 31-510 Kraków, Poland, e-mail: godlewsb@uek.krakow.pl (ORCID: https://orcid.org/0000-0001-9668-458X).
} 
their components in a dynamic and network form and cannot simplify the reality, focusing only on one group of business components and ignoring the other. These unique studies provide a valuable outlook to establish dynamic, adaptive business pathways towards a sustainable and resilient organizational future and propose future research paths needed to execute structural changes in businesses.

Keywords: business model, innovation, critical success factors, digital transformation, knowledge management, talent management, competitiveness, leadership, transformation, change management, VUCA

\section{INTRODUCTION}

Donald Rumsfeld (a former US Defense Secretary) said in 2001 "we are now living in a world which combines known knowns, known unknowns, and unknown unknowns" (Syrett \& Devine, 2012, p. 1). As a continuation, Syrett and Devine $(2012$, p. 2 ) point out that "the growth of the last category presents business leaders with a new and little charted management challenge." These words are still relevant nowadays after a lot of intensity we all faced from that time. The authors continued that when the environment is so uncertain, it is challenging to apply the traditional analytical tools to predict the future of businesses and choose a clear strategic direction. Tassabehij and Isherwood (2014), after research conducted in 47 countries, found there are similarities in each country and business sector in that, although managers use a variety of tools, they continue to use those that are well established and are focused on the management of internal and external resources. In contrast, novel strategies, tools, and disruptive technologies needed to foster innovative "blue oceans" and dynamic organizations to gain new markets are not widely applied in practice. Syrett and Devin (2012) asked several questions that are still valid today, like 1) What makes for a good strategy in highly uncertain business environments and modern economies? 2) How can organizations prepare themselves for the challenge of anticipating and responding to unanticipated events? and 3) What are the individual and organizational capabilities needed in uncertain and intense times?

Agility, resilience, digitalization, and sustainability are terms that are gaining more popularity in business and leadership during turbulent times. Miceli et al. (2021) present how these dimensions interact to help business to become strategically resilient. They offer a new view of resilience that includes a strategic attribute that could help companies capture change-related opportunities to design new ways of doing business under stress. An essential set of strategically agile processes, enabled by digitalization, creates strategic resilience that includes a proactive, opportunity-focused attitude in the face of change. Strategic resilience that leads to organizational sustainability is 
presented as a multi-domain concept similar to the holistic view of sustainability and its three components: environment, economy, and society.

The abovementioned dimensions are even more understandable and essential during the global crisis of the COVID-19 pandemic and will be in a "new normal" post-pandemic. Agility and resilience are among the most important and needed features for future challenges, business continuity, and their leaders post-pandemic (Nasser, 2021). Agility is an attribute that helped organizations survive and pass through the obstacles, especially those during COVID-19. Those who can adapt to those challenges, apply their lessons learned, and add new practices to react to the crisis might be called resilient. Chong et al. (2020) present five common characteristics that can help build agility in the "new normal": 1) Establish a common purpose and clear communication, 2) Set up structures to allow rapid decision making; 3) Create networks of local teams with transparent, accountable roles; 4) Develop a culture that empowers people; and 5) Provide people with the technology they need.

The pandemic has become a global catalyst for the information society's development that began many years ago, regardless of residence, age group, and educational level. People and organizations worldwide faced a considerable challenge and drastic change when almost every aspect of their professional and personal life was transformed into a virtual space. We were forced into international isolation, and digital technology has become a tool to continue all business functions and survive personally on many levels. As Kohnke (2016) presented, digitization changes the way of working and accelerates the speed of change that companies face. Some companies and people could accept the rapid and drastic change of reality and its ubiquitous virtualization faster. Their productivity and economic efficiency quickly returned to the pre-pandemic track. What makes them survive, adapt rapidly, and be resilient and prosperous during critical times? This question was and will be valid in the "new normal". The negative impact on many businesses during the pandemic was not only because of the lack of technological and systemic preparation to conduct business remotely but also the rigid organizational culture and lack of the proper mindset of the managerial staff to manage change in the VUCA (volatile, uncertain, complex, and ambiguous) world. Only those organizations with a leadership culture based on trust, effective communication, and empathy (competent leaders with well-developed "soft skills" to manage human resources) could succeed in these challenging times of digitalization and continuous change. From the beginning of the last decade, much has been written about the growing importance of non-technical/non-cognitive skills, also called the "soft skills" of the leaders and employees, to benefit business organizations 
due to the fourth industrial revolution, its technological advancement, and turbulent times (e.g., Bunker \& Wakefield, 2004; Dirani et al., 2020; Josten \& Lordan, 2021; Lepeley et al., 2021). Many organizations and managers undervalue that information. As underlined by Cukier et al. (2021), while a focus on technology skills dominates the discourse, particularly among large corporations, management, and leadership skills present a gap overall among manufacturing SMEs. Despite the preoccupation with technology skills, more SMEs fail because of a lack of other founders or founding team skills. In other words, the skills needed to manage ongoing innovation and growth are often disregarded because of an outsized focus on technology and technology skills.

The pandemic has fueled a surge in innovation, as necessity forced businesses, governments, and individuals to find ways to adapt. Not only has it driven the creation of new technologies, but it has also driven the development of new products and services, changes in processes, the development of new business models, and even shifts in the approach to work itself (Cukier et al., 2021).

As an immediate response to the global crisis observed worldwide, it is more critical than ever to present novel and interdisciplinary research, which will help leaders and businesses in developing and developed countries to be more prepared in challenging times. The research question (RQ) that guides this issue is:

RQ: What kind of entrepreneurship and success factors can help drive business to resilience and stability, and achieve competitive advantage through innovation in different countries and business realities in the era of digital transformation and turbulent times?

\section{LITERATURE BACKGROUND}

\section{Business challenges and its adaptability to change management in VUCA times}

Many challenging events happened during the last two decades. Some of them are turbulent ones, like the financial crisis in 2008 or the last one caused by the COVID-19 pandemic (Pena-Boquete \& Dios-Murcia, 2021; Rueda Cantuche, 2021). As Heraclitus said, "the only constant in life is change," and not only each of us should embrace the change to foster the development; businesses should also be prepared for unexpected future disruptive situations. 
Giones et al. (2019) use the turbulent context to immerse managers' decision-making processes and depict how the VUCA framework description by Bennett and Lemoine (2014) helps identify, map, and prepare an organization to respond to volatility, uncertainty, complexity, and ambiguity in the short and long term. Managing change and crisis in an organization during turbulent times requires the organization and its leaders to be flexible, react quickly, adapt, and reorganize its talents, competencies, and resources. The authors proposed a two-step approach to put the VUCA framework to work and thus support managers in the position of making strategic choices regarding how to respond to the VUCA challenges in their industries: 1) Breaking down the perception of uncertainty using the VUCA framework; 2) Preparing the organization to take action: choices and timing. Concerning the first stage, Giones et al. (2019) point out that this is not because we aim to convert reality into a dashboard of indicators, but rather to decipher what is uncertain, volatile or complex, and ambiguous. The objective of this first step is to break down the sources of what we commonly call uncertainty. The second recommended step involves preparing the organization to take action. These represent a portfolio of responses that managers in VUCA contexts can activate, e.g., the actions to respond to volatility are substantially different from those to respond to ambiguity. Concerning volatility, the focus is on isolating and creating mechanisms that can buffer or compensate for the effects (e.g., additional unexpected costs). In the long term, actions related to changing the degree of vertical integration of the business should also be considered. The authors indicated that ambiguity requires actions that introduce internal changes to the organization's culture. Making short-term changes opens further options for organizational change in the long term. The suggestions of ways to respond to complexity are linked to the necessity of understanding and controlling the outcomes of the company actions such that valuable knowledge of the situation to help the organization broaden its mindset regarding the problem and alternative future scenarios.

Change management requires a new look at many aspects of the company's functioning. Organizations that want to survive and thrive during challenging times also focus on innovation inside their business model. Business model innovation (BMI) is a growing field of discussion in business model (BM) research that mainly focuses on three aspects: value proposition, value creation, and value capture (Dyduch, 2019). BMI is a crucial issue in innovation research where these three elements or their relationships to each other are innovated (Filser et al., 2021). Filser et al. (2021) created a holistic framework for BMI based on the existing core in the literature and emerging trends. The authors of the study identified four core literature streams: value creation through $\mathrm{BMI}$, strategic $\mathrm{BM}$ concepts, design of the $\mathrm{BM}$ and its 
connection to entrepreneurship, and the interrelation of BM and strategy. Filser et al. (2021) highlight that, besides BMI's dynamic capabilities and small- and medium-sized enterprises, sustainability is the most crucial trend. The study also integrates into the research the intersection of sustainability and innovation, which is also recently investigated by Bocken et al. (2021), Gurzawska (2021), and Veldhuizen (2021), and adjusted to a business model to create business model innovation for sustainability (Preghenella \& Battistella, 2021; Pichlak \& Szromek, 2021; Pieroni et al., 2021).

Development of a business model innovation starts from typology to support strategic decision-makers in identifying and analyzing various options, evaluating their consequences, including performance effects and determining the business model innovation(s) most suitable for the company, as presented by Taran et al. (2015). The authors started by introducing and then offering a response to five fundamental questions that management needs to answer when considering innovating their business model: 1) What should we innovate? 2) How far do we go? 3) How will the innovation support our business strategy? 4) Do we adopt a closed or open approach to innovation? 5) When do we consider the business model innovation a success? The results of the study made by Taran et al. (2015) suggest that the success of the innovation depends on, among others, the company's appreciation of the new business model's innovativeness. Apart from the balance that needs to be found between the innovativeness (radicality, reach, complexity), strategic context (proactiveness), and organizational setting (openness) of the innovation.

Innovation creation in organizations during challenging times depends on the climate inside the organization that focuses on human abilities, creative ideas, and employees' motivation to add value to the organization. As Masumba (2019) points out, the climate for innovation inside organizations is generated mainly by human abilities. The author presents two groups of innovation skills: 1) Innovation management skills; 2 ) Innovation engagement skills. The first group involves creating and implementing organization-wide innovation support systems (innovation-support strategies, policies, procedures, plans, innovation-development processes, and workforce innovation skilldevelopment programs). The second group involves applying skills and abilities by organizational leaders to create and implement organization-wide, innovation-support initiatives aimed at specifically engaging and installing innovation in the hearts and minds of workforces. Apart from human skills, non-human abilities make a climate for innovation in an organization: research and development (R\&D) and innovation-support technologies. Many authors linked change management to the effect of technological disruptions and 
a digitalization wave across industries that spawned new digital opportunities and challenges for established firms (Giones et al., 2018).

\section{Digital transformation vs. business transformation and virtual leadership}

Digital transformation is a type of business transformation driven by emerging technologies (Tang, 2021). As mentioned by the author, the applicability of technology is mainly dependent on the industry and organization. It might include social media, mobility, the Internet of Things (IoT), cybersecurity, big data and analytics, cloud computing, robotic process automation (RPA), artificial intelligence (namely machine learning), blockchain, and others. With these technology trends, businesses are armed with the capability to digitize, transform, and grow their organizations fully. But these digitally sophisticated technologies are usually integrated by digitally mature organizations. In contrast, as underlined by Kane et al. (2015), less digitally mature businesses focus on solving strategic problems using individual digital technologies like e-commerce sites, social media analytics, and mobile applications. Kane et al. (2015) found out in their study that employees across all age groups want to work for businesses deeply committed to digital progress. This result is relevant for leaders to attract and retain the best talent.

As Philip (2021) emphasizes, digital transformation is mainly studied through information technology and strategic management. There are a deficient number of studies discussing digital transformation from an organizational behavior (OB) perspective. The author pointed out that the presentations of the organizational changes made by digital transformation focused on internal processes, mainly ignoring the consequences of such changes on people. For that reason, future research should also be more focused on the transformational leadership concept, significantly differentiating the role of leaders and their behaviors in planned or forced business digital transformation. Besides, there is a lack of studies presenting the pathways for sustainable talent management during digital transformation, especially those from traditional professions, less digitally mature businesses, and developing countries. The leadership concept should be integrated into the digital transformation theme, as corporate leaders are heavily involved in creating a new vision and implementing plans for the business transformation. Recent advancements in emerging technologies are redefining the managerial roles of managers. The deployment of artificial intelligence (AI) and remote intelligence (RI) technologies makes outsourcing easier for organizations. As a result, managers at all levels have to learn how to plan, organize, lead, and control virtual, cross-cultural teams and 
tackle "globotic upheavals" regarding inequality, job displacement, and unemployment in organizations (Song Ng, 2021).

Nowadays, much research is related to the business transition to organizations 4.0 and the adoption of smart technology (STs) gains in productivity, better control over operations and supply chain processes, and improved competitiveness (Gastaldi et al., 2022; Rymarczyk, 2020). Frank et al. $(2019$, p. 3 ) conceptualized Industry 4.0 as "a new industrial maturity stage of product firms, based on the connectivity provided by the industrial Internet of Things, where the companies' products and processes are interconnected and integrated to achieve higher value for both customers and the companies' internal processes." Lyke-Ho-Gland et al. (2019), in the APQC report, show where organizations are along the path of digital transformation and how they evaluate these initiatives' progress and success. The data obtained from the survey done in more than 25 industries and 304 valid participants show that organizations are proceeding rapidly through their digital transformation journeys $-43 \%$ are already in their first or second wave of digital projects while $39 \%$ of the organizations have a centrally managed portfolio of digital projects with an overarching strategy. The authors present the top drivers (goals) behind digital transformations: (a) optimize core business processes $38.8 \%$; (b) build efficiencies through automation - 37\%; (c) improve customer experience $-29.1 \%$; (d) move systems to a cloud or mobile environment $20.8 \%$; establish real-time data capabilities $-18 \%$. An overwhelming majority (95.4\%) of organizations use explicit measures to track the effectiveness and success of their digital transformations. $63.3 \%$ use operational measures to track their digital transformations. Within this category, most companies respond that they measure productivity $(66.9 \%)$ and quality $(59.6 \%)$ to monitor the efficiency and efficacy of core business processes. In third place are innovation and collaboration measures. Both gain $40.4 \%$ of responses. More than half $(55.8 \%)$ of organizations use financial measures to track the success of their digital transformations to make sure they get a return from investment. The popular measures are cost reductions (63.6\%) and ROI (56.1\%). Concerning implementation measures, $40 \%$ of respondents, including this one, are the most important project milestones (77.2\%). Customer measures are used less often (39.2\%) than the other three to track digital transformations. However, the customer satisfaction index is by far the most common customer measure (71.4\%).

The pandemic impacted the transition to digital transformation in a massive form and increased the interest in virtual team leadership as an emerging research theme. A virtual team might be presented as the one that "has members who potentially span different organizations, time zones, geographic locations, and cultures with technology enabling communication 
and coordination between members" (Huang et al., 2010, p. 1098). For many companies and leaders, remote management of people and business, where survival is important, but health and human life is a priority, is a new, so far unknown challenge. COVID-19 introduced a sense of threat to life, health, material security, and social isolation (e.g., Loan et al., 2021; Marona \& Tomal 2020). Good virtual leaders can be seen as a lifebuoy for struggling businesses. The argument for virtual leadership to keep organizations operational is especially timely in helping leaders deal with the challenges of running organizations remotely (Thambusamy, 2020).

Many research studies show the harmful effects of a pandemic and physical distancing on people's mental health (Rohde et al., 2016; Galea et al., 2020; Banerjee \& Rai, 2020). Hence, human-based factors, especially soft skills, have become crucial in an organization's digital transformation and successful implementation (Gulati \& Raiche, 2020; Ziadlou, 2021). The leaders' empathy towards their co-workers and the ability to manage their own and others' emotions and resistance to change increases the sense of psychological security in the organization and impacts employee engagement. Empathetic management, a complete understanding of employees and customer needs minimizes the stress level of employees. It allows for the development of products and services to meet recipients' needs better. Employees are characterized by more outstanding commitment and motivation to share knowledge and ideas to find the optimal solution in turbulent change and digital technology. As Hoque et al. (2017) argued, employee engagement can interact in the relationship between corporate entrepreneurship and innovation performance.

Sariwulan et al. (2021) present in their study that transformational leadership has the most significant influence on employee talent management rather than organizational culture and work division. The impact of leadership is related to the visionary view of achieving better results in the future, acting as agents of change, acting transparently and democratically, giving trust to employees, and developing togetherness to achieve company progress. On the other hand, employee talent management impacts job satisfaction, performance, and commitment to work sustainability (Pauli \& Pocztowski, 2019). The application of employee talent management will not positively impact if, as underlined by the authors, workers do not feel the benefits, increase income, provide career certainty, fulfillment of guaranteed rights, work quality, timeliness, loyalty, work passion, and others. Lack of knowledge or familiarity with these technologies' features and potential benefits generates resistance to change. Fear and aversion amongst people raise against that business technological transformation (Palomares et al., 2021). There is a significant need to research digital transformation, 
transformational leadership, and employees' behavioral changes towards business sustainability transformations.

\section{THE CONTRIBUTIONS}

The articles in this issue provide several themes based on quantitative and qualitative research, critical literature reviews made in different countries (the USA, Finland, Poland, Ukraine, and Nigeria), and business realities in the era of digital transformation and turbulent times. The research was related to various aspects of a business functioning to be more resilient and stable and achieve competitive advantage through innovation: (a) interactive effects of the factors affecting the success of a startup enterprise, (b) value chain benchmarking to identify innovative digital technologies and the benefits of their application, (c) entrepreneurial self-efficacy and entrepreneurial intention's impact to start a business venture among young graduates, (d) analysis of knowledge management initiatives, policies and tools application in small, medium, and large enterprises, (e) analyze the importance of internal capabilities (resources) and external information sources in implementing the product, process, marketing, and organizational innovations to maximize the firm's competitive advantage and create value for stakeholders.

The unique part of Keogh and Johnson's research is to test the interactive effects of factors affecting the success of a startup enterprise. In the existing literature on the subject, the emphasis is on investigating those factors in an individual form and not presenting interactive effects. The authors model and test potential complementarities between financing strategies and the personal attributes of the entrepreneurs, using survival rates as a measure of success. A Cox proportional-hazard model was used to estimate longevity in startups, and two metrics of success and their interactions were calculated: employment and revenue. The research results show that angel investors and venture capital investors benefit differently from founders with industry experience; founders with higher educational achievement generate more revenue than their peers, specifically when their startups collaborate in university partnerships. This presented article is the first to explicitly and empirically test for the presence of those complementarities.

In the article of Potoczek, different types and models of benchmarking in the water supply industry are presented. The approach to benchmarking is an original concept based on analyzing the value chain and digital maturity of business processes. The attempt made in the article to develop benchmarking research with an analysis of the value chain, allows for identifying innovations undertaken by enterprises from the perspective of implemented processes 
that create a dynamic, multi-instance structure of tasks, resources, and technological competencies. The concept of using value chain benchmarking is to identify innovative digital technologies and the benefits of their application in achieving higher effectiveness in obtaining goals and taking up new civilization challenges. The concept of researching technological changes in the value chain requires a reference to research on the digital maturity of enterprises, the nature of benchmarking research in the selected water supply industry, and the possible use of value chain analysis. Analysis of the decomposition of the water supply company's value chain, criteria, and levels of process maturity assessment, as well as the types and advancement of digital technologies, makes it possible to prepare two scenarios of digital technology benchmarking stages depending on the level of process maturity and the propensity to invest in business process management.

The process-benchmarking concept presented in this article is used for the first time by water supply companies. Nevertheless, the results of benchmarking research should be an essential source of information both for entities with water resources and for users themselves, for whom access to clean water is vital and who must accept the price of water is dictated by suppliers. Potoczek developed the benchmarking research concept through literature studies and identifying research problems and ideas on internet platforms operated by enterprises, associations, and foundations. Research methods presented in the article have grown in popularity in the literature, but their relationship to the context of the water industry is an innovative approach by the author.

Osadolor, Agbaeze, Isichei, and Olabosinde, through the lens of behavioral reasoning theory, present an entrepreneur's intent to start a business venture among young graduates in Nigeria. The authors focus on assessing the direct effect of entrepreneurial self-efficacy (ESE) and entrepreneurial intention (EI) and the indirect impact of the need for independence on the relationship between the constructs. The authors indicated that the business climate in Nigeria offers little to young adults in terms of support towards venture creation. It thus implies that developing the need for independence as an entrepreneur could account for the process through which their selfbelief is triggered towards steering the need to start, own and manage a venture. In the presented research, a quantitative approach was applied. Data was collected using a questionnaire form from 235 Nigerian graduates participating in the National Youth Service Corp in twelve states in Nigeria. Analysis was made using a partial least square structural equation model. The results from the study show that self-efficacy does not significantly affect intention, and the need for independence affects entrepreneurial 
intention. The need for autonomy fully mediates the relationship between entrepreneurial self-efficacy and entrepreneurial intention.

The purpose of the original study, done for the first time in the transition economies of post-Soviet states by Sytnik and Kravchenko, was to conduct a comparative analysis of knowledge management (KM) initiatives in small, medium, and large enterprises operating in Ukraine, and highlight the specific characteristics of knowledge management policies, as well as the scope and intensity of knowledge management tools application in these categories. Knowledge management is an intensely researched topic in the literature, but there are limited studies on the KM differences in small, medium, and large enterprises. The empirical data were obtained through a questionnaire survey among 90 managers and analyzed statistically. Regardless of the size, all enterprises showed a high awareness of knowledge/KM importance for their business. In contrast to the standard view on SMEs as a homogeneous sector in knowledge management, the study shows its heterogeneity in knowledge management initiatives. The differences were observed, especially between small and large enterprises. In the case of large enterprises, high awareness of KM importance was highly consistent with implementing KM policies at organizational procedures. On the contrary, small enterprises demonstrated apparent inconsistency between declared attitude to $\mathrm{KM}$ and actual implementation of KM policies at an executive level. Medium enterprises were more similar to large enterprises in their actions.

The theoretical contribution of this study was the provision of SMEs sector heterogeneity evidence based on several knowledge management characteristics presented in the article. This finding allows us to deepen our knowledge of conceptual differences in knowledge management approaches applied by different enterprise categories. While designing specific knowledge management policies, programs, and tools, the size of the enterprise is essential in considering how to meet its needs. The larger the enterprise is, the more structured, deliberate, and conscious the knowledge management approach that should be applied.

The article by Littunen, Tohmo, and Storhammar aims to analyze the importance of internal capabilities (resources) and external information sources in implementing the product, process, marketing, and organizational innovations to maximize the firm's competitive advantage and create value for stakeholders. Furthermore, it examines the role of public organizations, business networks, firm size, and the industry sector in the emergence of different product types, processes, marketing, and organizational innovations. The research is based on the typology of innovation (product, process, marketing, and corporate) adopted by the OECD. The data from 389 SMEs in Finland were used for further calculations. Data were collected through 
telephone interviews with industrial SMEs and KIBS-based companies in autumn 2017 and spring 2018. Samples from SMEs of different sizes and regions were purchased from Statistics Finland. The logistic regression analysis was applied to determine the stakeholders (various information sources) and firm-level characteristics that distinguish noninnovative and innovative companies based on the sample. The study analyzes to what extent different types of innovation rely on specific information sources.

Contrary to expectations, public support organizations were not statistically significant in any innovation model. Therefore, public support organizations should develop better mechanisms to find SMEs with solid motivations to create new products and market opportunities. The results show that creating novel products, processes, and marketing innovation is related to various external sources of information, such as fairs, the media, and the Internet. Moreover, the relationship between internal capabilities such as the firm's know-how increases SMEs' marketing and organizational innovativeness. Furthermore, the design of novel processes and corporate innovation is related to firm size. Those with less than 20 employees (smallest firms) concentrated among non-innovators, and companies with more than 20 employees focused on innovators.

The study provides comprehensive information on how different stakeholders contribute to the emergence of SME innovation. The article's authors offer a new viewpoint on the literature by examining the possible factors explaining the increase in SMEs' likelihood of implementing the product, process, marketing, and organizational innovations.

\section{FUTURE RESEARCH}

The articles in this issue suggest implications for further theoretical and practical research. In the article of Keogh and Johnson, we can find specific ways of entrepreneurs' financing options as complements to their founder attributes. We can find inspiration for future research related to the indicators of success and give advice to policymakers, financiers, and entrepreneurs because of the nuanced nonlinearities and interactions demonstrated. This research and its continuation are needed to help investors make proper decisions. As presented in the article, industry experience was most effective when combined with angel investing (to achieve revenues and employment), whereas industry experience combined with venture capital worked against success. This new finding is consistent with the existing literature on the subject and explains differences between the outcomes of the previous studies presented in the author's article. It may be interpreted by the startup's 
control and strategic direction (hearkening back to Cooper et al., 1994), but it needs further research on this question.

Potoczek creates a conceptual benchmarking model that needs validation in pilot studies to verify the value chain's levels of detail. The author also formulates a need to develop research methods to build knowledge about technological and organizational innovations and their use, which significantly improve the efficiency of water utilities and the availability of their products and services.

Osadolor, Agbaeze, Isichei, and Olabosinde gave us an outlook on future studies needs as a continuation of their research related to the factors that could support young graduate interest in venture creation. The presented study's objective was to broaden understanding of how the need for independence indirectly accounts for the process between Nigerian graduates' self-efficacy and entrepreneurial intention. The results of the study help conclude that graduates' self-belief could not drive the choice to start a venture, but the impact might come from an external factor(s). The authors underlined that the decision not to open a business might be related to the evident inability to access capital or support funds required to establish a business of their own and the hostile business climate in Nigeria that is relatively harsh to new entrants. Further research is needed to understand the motivations and future needs of potential young entrepreneurs to develop a business in Nigeria, which helps to fight the high unemployment rate in the country that is forecasted to grow in 2022 from $32.5 \%$ (2021) to $33 \%$. Also, what kind of governmental help is needed to convince a young graduate to choose the entrepreneurship route?

Sytnik and Kravchenko suggested the directions for further research related to knowledge management studies. Comparing the characteristics of knowledge management between small, medium, and large enterprises allow one to understand better the features of KM policies, procedures, tools, and practices among various sizes. The question is: does a less structured, less consistent, and less conscious knowledge management approach demonstrated by small enterprises satisfy their knowledge needs in the same way that a structured, consistent and deliberate knowledge management approach could fulfill the knowledge needs of larger enterprises? Further research is needed to determine how the different knowledge management approaches applied by small, medium, and large enterprises affect the efficiency of decision-making processes, organizational productivity and, ultimately, organizational competitiveness.

In the article of Littunen, Tohmo, and Storhammar, further research was suggested concerning different types of innovations in SMEs. There is a need to examine the companies in more detail and carefully decide the choice of 
a sample (single industry, various industries) and country(ies) to do the research. Also, comparative studies are needed to understand better the differences and standard features of innovation activities in different organizations.

\section{CONCLUSION}

This article synthesizes the interdisciplinary research presented in this issue with the narrative literature review to explore what entrepreneurship and success factors can help drive business to resilience and stability and achieve competitive advantage in the fourth industrial revolution, technological advancement, and turbulent times. In conclusion, these factors can be grouped as (1) human-based factors and (2) non-human-based factors. In the first group, we have (a) competent, responsible, and open-minded leaders with well-developed soft skills to manage human resources. They can bring and maintain talent in an organization. Their attitude shows that they are open to embracing change, try to be flexible and adapt rapidly, and distribute that mindset within their staff; (b) talented employees, who want to share their experience and knowledge, are motivated, committed to supporting the organization in challenging moments, and want to learn to adapt rapidly in the future. The second group of factors is a compound of (a) business culture that empowers people (based on trust, effective communication, and empathy); (b) business model and its transformation to create business model innovation for sustainability; (c) novel strategies in a highly uncertain business environment (also financing one, related to personal attributes of the entrepreneurs); (d) support (disruptive) technologies that depend on the digital maturity of the business to foster its innovation and sustainability transitions.

The world is complex, and we cannot try to simplify it. Still, we should embrace the complexity by identifying and applying a new way of thinking and solving the problems in an organization (Rzevski \& Brebbia, 2016). Each group of the above-presented factors is essential for business success, and their components are interdependent. We need to look at the interactions and interdependencies of their components in a dynamic and network form, e.g., as presented by Ujwary and Potoczek (2020), Lombardi Netto et al. (2020), or Greda (2009). Each company is different and is dependent on many factors that differentiate them: talented people (leaders and employees), its organizational, financial, technical and technological, environmental, social, political, and other components. That is why it cannot be simplified, focusing only on one group of factors and ignoring the other.

To balance the business necessities vs. opportunities that appear in a complex (VUCA) world, open-minded leaders are needed who are not 
afraid to apply novel tools and strategies to solve the problems in their organizations by looking at them holistically. As underlined by Philip (2021), leaders should be paying attention to changing employee attitudes during a digital transformation. The business transformation will be successful only when employees are wholeheartedly committed to the company's vision and not merely when the company successfully installs some of the new and emerging technologies and implements changes. That is why humanbased factors, especially the soft skills of leaders, have become crucial in an organization's digital transformation and its success in turbulent times. There is a significant need to study digital transformation, transformational leadership, and employees' behavioral changes towards business sustainability transformations. Especially, there is a necessity to present pathways for sustainable talent management during digital transformation, taking into account traditional professions, less digitally mature businesses, and developing countries.

These unique studies presented in this issue provide a valuable outlook to establish dynamic, adaptive business pathways towards a resilient and sustainable organizational future, and propose future research paths needed to execute structural business changes in different countries and business areas. Recommendations and implications for the future trends of this research stream might also be helpful for professionals and academicians.

\section{References}

Banerjee, D., \& Rai, M. (2020). Social isolation in Covid-19: The impact of Ioneliness. International Journal of Social Psychiatry, 66(6). https://doi. org/10.1177/0020764020922269

Bennett, N., \& Lemoine, G. J. (2014). What a difference a word makes: Understanding threats to performance in a VUCA world. Business Horizons, 57(3), 311-317. https://doi.org/10.1016/j.bushor.2014.01.001

Bocken, N., Weissbrod, I., \& Antikainen, M. (2021). Business experimentation for sustainability: Emerging perspectives. Journal of Cleaner Production, 281(4). https://doi.org/10.1016/j.jclepro.2020.124904

Bunker, K., \& Wakefield, M. (2004). In search of authenticity: Now more than ever, soft skills are needed. Leadership in Action, 24(1), 17-21. https:// doi.org/10.1002/lia.1055

Chong, E., Handscomb, C., Williams, O., \& Hall, R. (2020). Agile resilience in the UK: Lessons from COVID-19 for the "next normal." McKinsey \& Company. Retrieved from https://www.mckinsey.com/businessfunctions/organization/our-insights/agile-resilience-in-the-uk-lessonsfrom-covid-19-for-the-next-normal

Cukier, W., Mccallum, K.E., Egbunonu, P., \& Bates, K. (2021). The mother of invention: Skills for innovation in the post-pandemic world. The Future 
Skills Centre Report. Canada. Retrieved from https://www.ryerson.ca/ diversity/reports/MotherOfInvention_EN.pdf

Dirani, K.M., Abadi, M., Alizadeh, A., Barhate, B., Garza, R. C., Gunasekara, N., Ibrahim, G., \& Majzun, Z. (2020) Leadership competencies and the essential role of human resource development in times of crisis: A response to Covid-19 pandemic. Human Resource Development International, 23(4), 380-394. https://doi.org/10.1080/13678868.2020.1780078

Dyduch, W. (2019). Entrepreneurial strategy stimulating value creation: Conceptual findings and some empirical tests. Entrepreneurial Business and Economics Review, 7(3), 65-82. https://doi.org/10.15678/ EBER.2019.070304

Filser, M., Kraus, S., Breier, M., Nenova, I., \& Puumalainen, K. (2021). Business model innovation: Identifying foundations and trajectories. Business Strategy and the Environment, 30(2), 891-907. https://doi.org/10.1002/ bse. 2660

Frank, A., Mendes, G., Ayala, N., \& Ghezzi, A. (2019). Servitization and Industry 4.0 convergence in the digital transformation of product firms: $A$ business model innovation perspective. Technological Forecasting and Social Change, 141, 341-351. https://doi.org/10.1016/j.techfore.2019.01.014

Galea, S., Merchant, R. M., \& Lurie, N. (2020). The mental health consequences of COVID-19 and physical distancing. The need for prevention and early intervention. JAMA Internal Medicine, 180(6), 817-818. https://doi. org/10.1001/jamainternmed.2020.1562

Gastaldi, L., Lessanibahri, S., Tedaldi, G., \& Miragliotta, G. (2022). Companies' adoption of Smart Technologies to achieve structural ambidexterity: An analysis with SEM. Technological Forecasting and Social Change, 174. https://doi.org/10.1016/j.techfore.2021.121187

Gręda, A. (2009). Application of the AHP/ANP in food quality management. Retrieved from http://www.isahp.org/2009Proceedings/Final_ Papers/98_Greda_ANP_in_FoodQualityManagement.pdf

Giones, F., Brem, A., \& Berger, A. (2019). Strategic decisions in turbulent times: Lessons from the energy industry. Business Horizons, 62(2), 215225. https://doi.org/10.1016/j.bushor.2018.11.003

Gulati, R., \& Reaiche, C. H. (2020). Soft skills: A key driver for digital transformation. Retrieved from https://www.researchgate.net/profile/ Richa-Gulati/publication/346171713_Soft_Skills_A_Key_Driver_for_ Digital_Transformation/links/5fbca7c0a6fdcc6cc65e-38e1/Soft-Skills-AKey-Driver-for-Digital-Transformation.pdf

Gurzawska, A. (2021). Responsible innovation in business: Perceptions, evaluation practices and lessons learned. Sustainability, 13. https://doi. org/10.3390/su13041826

Hoque, A.S., Gwadabe, U.M., \& Rahman, A. (2017). Corporate entrepreneurship upshot on innovation performance: The mediation of employee engagement. Journal of Humanities, Language, Culture, 
and Business, 1(6), 54-67. http://inderscience.metapress.com/link. asp?id=py74f67qv8xevf83

Huang, R., Kahai, S., \& Jestice, R. (2010). The contingent effects of leadership on team collaboration in virtual teams. Computers in Human Behavior, 26(5), 1098-1110. https://doi.org/10.1016/j.chb.2010.03.014

Josten, C., \& Lordan, G. (2021). The accelerated value of social skills in knowledge work and the COVID-19 pandemic. LSE Public Policy Review, 1(4), 1-10. https://doi.org/10.31389//seppr.31

Kane, G., Palmer, D., Phillips, A., Kiron, D., \& Buckley, N. (2015). Strategy, not technology, drives digital transformation. MIT Sloan Management Review, July 14. Retrieved from https://sloanreview.mit.edu/projects/ strategy-drives-digitaltransformation/

Kohnke, O. (2016). It's not just about technology: The people side of digitization. In G. Oswald \& M. Kleinemeier (Eds.), Shaping the Digital Enterprise. Trends and Use Cases in Digital Innovation and Transformation (pp. 69-91). Berlin: Springer International Publishing. https://doi. org/10.1007/978-3-319-40967-2_3

Lepeley, M. T., Beutell, N. J., Abarca, N., \& Majluf, N. (2021). Soft Skills for Human-Centered Management and Global Sustainability. New York: Routledge.

Loan, L., Doanh, D., Thang, H., Viet Nga, N., Van, P., \& Hoa, P. (2021). Entrepreneurial behaviour: The effects of the fear and anxiety of Covid-19 and business opportunity recognition. Entrepreneurial Business and Economics Review, 9(3), 7-23. https://doi.org/10.15678/ EBER.2021.090301

Lombardi Netto, A., Salomona, V.A.P., Ortiz-Barrios, M. A., Florek-Paszkowska, A., Petrillo, A., \& De Oliveira, O. J. (2020). Multiple criteria assessment of sustainability programs in the textile industry. International Transactions in Operational Research, 28(3), 1-23. https://doi.org/10.1111/itor.12871

Lyke-Ho-Gland, H., Trees, L., \& Morgan, L. (2019). Measures of digital transformation. APQC Survey Summary Report. Retrieved from https:// www.apqc.org/resource-library/resource-listing/measures-digitaltransformation-survey-report

Marona, B., \& Tomal, M. (2020). The COVID-19 pandemic impact upon housing brokers' workflow and their clients' attitude: Real estate market in Krakow. Entrepreneurial Business and Economics Review, 8(4), 221232. https://doi.org/10.15678/EBER.2020.080412

Masumba, D. (2019). Leadership for Innovation: Three Essential Skill Sets for Leading Employee-Driven Innovation. New York: Morgan James Publishing.

Miceli, A., Hagen, B., Riccardi, M., Sotti, F., \& Settembre-Blundo, D. (2021). Thriving, not just surviving in changing times: How sustainability, agility, and digitalization intertwine with organizational resilience. Sustainability, 13(4). https://doi.org/10.3390/su13042052 
Nasser, W. (2021). Innovation capital, sustainable entrepreneurial orientation, and the moderating role of entrepreneurial resilience. Entrepreneurial Business and Economics Review, 9(3), 73-85. https://doi.org/10.15678/ EBER.2021.090305

Palomares, I., Martínez-Cámara, E., \& Montes, R. (2021). A panoramic view and SWOT analysis of artificial intelligence for achieving the sustainable development goals by 2030: Progress and prospects. Applied Intelligence, 51, 6497-6527. https://doi.org/10.1007/s10489-021-02264-y

Pauli, U., \& Pocztowski, A. (2019). Talent management in SMEs: An exploratory study of polish companies. Entrepreneurial Business and Economics Review, 7(4), 199-218. https://doi.org/10.15678/EBER.2019.070412

Pena-Boquete, Y., \& Dios-Murcia, I. (2021). Factors behind the employment loss in Galicia: Great Recession of 2008 vs. the first wave of the COVID-19 pandemic. Revista Galega De Economía, 30(1), 1-18. https://doi. org/10.15304/rge.30.1.7451

Philip, J. (2021). Viewing digital transformation through the lens of transformational leadership. Journal of Organizational Computing and Electronic Commerce, 31(2), 114-129. https://doi.org/10.1080/1091939 2.2021.1911573

Pichlak, M., \& Szromek, A.R. (2021). Eco-innovation, sustainability and business model innovation by open innovation dynamics. Journal of Open Innovation: Technology, Market, and Complexity, 7(2). https://doi. org/10.3390/joitmc7020149

Pieroni, M., McAloone, T., \& Pigosso, D. (2021). Circular economy business model innovation: Sectorial patterns within manufacturing companies. Journal of Cleaner Production, 286. https://doi.org/10.1016/j. jclepro.2020.124921

Preghenella, N., \& Battistella, C. (2021). Exploring business models for sustainability: A bibliographic investigation of the literature and future research directions. Business Strategy and the Environment, 30(5), 25052522. https://doi.org/10.1002/bse.2760

Rohde, N., D’Ambrosio, C., \& Tang, K.K. (2016). Estimating the mental health effects of social isolation. Applied Research Quality Life, 11, 853-869. https://doi.org/10.1007/s11482-015-9401-3

Rueda Cantuche, J. M. (2021). The economy of the European Union in times of COVID-19. Revista Galega De Economía, 30(1), 1-17. https://doi. org/10.15304/rge.30.1.7663

Rymarczyk, J. (2020). Technologies, opportunities and challenges of the industrial revolution 4.0: Theoretical considerations. Entrepreneurial Business and Economics Review, 8(1), 185-198. https://doi.org/10.15678/ EBER.2020.080110

Rzevski G., \& Brebbia, C. A. (2016). Complex Systems. Fundamentals and Applications. Southampton, Boston: WIT Press.

Sariwulan, T.., Thamrin, S., Suyatni, M., Agung, I., Widiputera, F., Susanto, A. B., \& Capnary, M. C. (2021). Impact of employee talent 
management. Academic Journal of Interdisciplinary Studies, 10(5), 184. https://doi.org/10.36941/ajis-2021-0133

Song $\mathrm{Ng}, \mathrm{H}$. (2021). Are managers still necessary in the era of the fourth industrial revolution (14.0)? In Future of Work, Work-Family Satisfaction, and Employee Well-Being in the Fourth Industrial Revolution (pp. 81-98). Pennsylvania: IGI Global: International Academic Publisher. https://doi. org/10.4018/978-1-7998-3347-5.ch006

Syrett, M., \& Devine, M. (2012). Managing Uncertainty: Strategies for Surviving and Thriving in Turbulent Times. Hoboken, NJ: Wiley.

Tang, D. (2021). What is digital transformation? The EDP Audit, Control, and Security Newsletter, 64(1), 9-13. https://doi.org/10.1080/07366981.202 0.1847813

Taran, Y., Boer, H., \& Lindgren, P. (2015). A business model innovation typology. Decision Sciences, 46(2), 301-331. https://doi.org/10.1111/deci.12128

Tassabehji, R., \& Isherwood, A. (2014). Management use of strategic tools for innovating during turbulent times. Strategic Change: Briefings in Entrepreneurial Finance, 23, 63-80. https://doi.org/10.1002/jsc.1960

Thambusamy, R., \& Zafer, B. (2020). Virtual leadership in small businesses during the COVID-19 pandemic: Challenges and possibilities. European Journal of Social \& Behavioural Sciences, 29(3), 3214-3224. https://doi. org/10.15405/ejsbs.2020.08.issue-3

Ujwary-Gil, A., \& Potoczek, N.R. (2020). A dynamic, network, and resourcebased approach to the sustainable business model. Electronic Markets, 30(4), 717-733. https://doi.org/10.1007/s12525-020-00431-6

Veldhuizen, C. (2021). Conceptualizing the foundations of sustainabilityfocused innovation policy: From constructivism to holism. Technological Forecasting and Social Change, 162(C). https://doi.org/10.1016/j. techfore.2020.120374

Ziadlou, D. (2021). Strategies during digital transformation to make progress in the achievement of sustainable development by 2030. Leadership in Health Services, 34(4), 375-391. https://doi.org/10.1108/LHS-08-20200056

\begin{abstract}
Abstrakt
CEL: Zbadanie, jakie czynniki przedsiębiorczości i sukcesu moga pomóc w osiqgnięciu odporności i stabilności biznesu oraz osiqgnnięciu przewagi konkurencyjnej dzięki innowacjom w różnych krajach i realiach biznesowych w erze transformacji cyfrowej i turbulentnych czasach. METODYKA: Na podstawie narracyjnego przeglqdu literatury przedstawiamy wyniki badań dotyczqcych nowych strategii i perspektyw dla innowacji biznesowych w czasach wielu niewiadomych. Każda organizacja chce znaleźć drogę do sukcesu i stworzyć swój unikalny model biznesowy, który może uchwycić tworzenie wartości i innowacyjność oraz być bardziej adaptacyjnym, odpornym i stabilnym w krytycznych momentach oraz zrównoważonym w czasie. WYNIKI: Artykuły przedstawione w tym numerze pozwalajq odkryć podstawowe czynniki innowacyjności i sukcesu biznesowego w różnych organizacjach i środowiskach, w których te
\end{abstract}


przedsiębiorstwa funkcjonujq. IMPLIKACJE DLA TEORII I PRAKTYKI: W artykule dokonano syntezy znaczenia prezentowanego pola badawczego, łq̨czqc jego teoretyczne tło z praktycznymi badaniami. Zalecenia i implikacje dla przyszłych trendów tego nurtu badawczego moga być również pomocne dla profesjonalistów i naukowców. ORYGINALNOŚĆ I WARTOŚĆ: Nowatorskie badania przedstawione w tym numerze zostały przeprowadzone w pięciu różnych (rozwijajqcych się i rozwiniętych) krajach i sektorach biznesu, które przedstawiajq różne ludzkie i pozaludzkie czynniki jako kluczowe do wzmocnienia transformacji biznesowej w złożonym świecie. Każda grupa elementów ma kluczowe znaczenie dla sukcesu biznesowego, a ich składniki sq od siebie współzależne. Musimy patrzeć na interakcje i współzależności jego komponentów w dynamicznej i sieciowej formie i nie możemy upraszczać rzeczywistości, skupiajqc się tylko na jednej grupie komponentów biznesowych, ignorujqc pozostałe. Te unikalne badania zapewniły cenna perspektywę ustanowienia dynamicznych, adaptacyjnych ścieżek biznesowych w kierunku zrównoważonej i odpornej przyszłości organizacyjnej oraz pozwoliły na stworzenie propozycji przyszłych ścieżek badawczych potrzebnych do przeprowadzenia zmian strukturalnych w przedsiębiorstwach.

Słowa kluczowe: model biznesu, innowacyjność, krytyczne czynniki sukcesu, transformacja cyfrowa, zarzq̨dzanie wiedzq, zarzqqdzanie talentami, konkurencyjność, przywództwo, transformacja, zarzqdzanie zmianq, VUCA

\section{Biographical notes}

Anna Florek-Paszkowska, Ph.D. in economics in management science, finished at the University of Warsaw, Poland. She works as a full-time professor at the Department of Management at Centrum Católica Business School PUCP (No.1 Business School in Peru and one of the best MBA business schools in the world with four accreditations). She is a student of prof. Thomas L. Saaty, USA (founder of Analytic Hierarchy and Network Processes - AHP/ ANP) with over 20 years of experience applying and teaching AHP/ANP. The author of over 60 scientific articles, cooperates as a reviewer with publishers, i.e., Springer, Taylor \& Francis, Emerald, Inderscience, International Journal of the Analytic Hierarchy Process, Associação Brasileira de Engenharia de Produção and Annals of Operations Research. She participated in eight research projects and the organization of international conferences and events in various countries. She is a member of the International Journal of the Analytic Hierarchy Process (IJAHP) editorial board.

Anna Ujwary-Gil, Ph.D. Hab., is professor at the Institute of Economics, Polish Academy of Sciences in Warsaw, Poland. She received her Ph.D. and habilitation in economics and management from the Warsaw School of Economics, Poland. She is founder and president of the Cognitione Foundation for the Dissemination of Knowledge and Science. Her research interests include social (organizational) network analysis, knowledge management, intellectual 
capital, resource-based views, and dynamic approaches to organization and management. She published her works in Library \& Information Science Research, Electronic Markets, Journal of Business and Industrial Marketing, or Economics \& Sociology.

Bianka Godlewska-Dzioboń, Ph.D., is assistant professor at the Cracow University of Economics (UEK) in the Department of Public Policies, Faculty of Public Economy and Administration. Moreover, she is the Vice-Rector for Cooperation and Development of the Podhale State Vocational University in Nowy Targ, Poland. Expert and trainer in research and implementation projects in the field of promoting academic entrepreneurship and competence development. Founder of the UEK Dialogue Laboratory, an initiative connecting the university community: students, research, and teaching staff with the business community and local government.

\section{Conflicts of interest}

The authors declare no conflict of interest.

\section{Citation (APA Style)}

Florek-Paszkowska,A.,Ujwary-Gil, A., \&Godlewska-Dzioboń, B.(2021).Business innovation and critical success factors in the era of digital transformation and turbulent times. Journal of Entrepreneurship, Management, and Innovation, 17(4), 7-28. https://doi.org/10.7341/20211741 